\title{
GENERAL MEETING OF COPARTNERS OF HABITATION PROPRIETORS: CARRYING OUT ORDER
}

\author{
Gazizullina Liliya Zakievna \\ Department of taxation \\ Institute of Management, Economics and Finance \\ Kazan Federal University \\ Kazan, Russia \\ E-mail: 89196873238@mail.ru
}

\author{
Tufetulov Ajdar Miralimovich \\ Department of taxation \\ Institute of Management, Economics and Finance \\ Kazan Federal University \\ Kazan, Russia \\ E-mail: ajdar-t@yandex.ru
}

\begin{abstract}
In the given paper, the authors try to classify the supreme body of management - general meeting of copartners of proprietors of habitation on the bases provided for classification of general meetings of proprietors and general meetings of shareholders. Allocating kinds of general meetings, the authors focus their attention on features of registrations, etc. Besides, by the results of the conducted research, the authors generalize some features of the supreme body of partnership management of habitation proprietors - a general meeting of copartners.
\end{abstract}

Keywords - meeting decision, partnership, proprietors, habitation, general meeting, premises proprietors, copartners

\section{INTRODUCTION}

Point 1 of clause 53 of the Civil code of the Russian Federation [1, 2], determining the legal entity as one of its signs, has specified availability of controls through which it acquires civil laws and undertakes civil obligations. One of such controls of the partnership of proprietors of habitation is a general meeting of copartners [3].

The question of ordering a general meeting of copartners of proprietors of habitation of great value.

So, with the introduction of relevant amendments to the civil law, there is such legal form as a partnership of owners of real estate, including homeowners.

Thus, according to the Federal Tax Inspectorate of the Russian Federation, today in the country 66,085 condominiums were registered, including 55768 homeowners; 11010 associations of property owners.

The results of the analysis of information registered in the regions of the Volga Federal District of the Russian Federation, homeowners and real estate are shown in table №1.

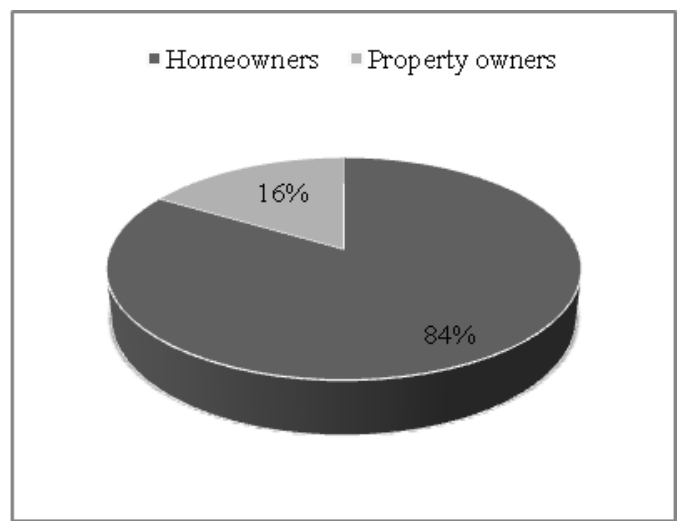

Fig. 1. The ratio of the number of homeowners partnerships with property owners (February 1, 2018), \%

TABLE I. THE NUMBER OF HOMEOWNERS, PROPERTY OWNERS ASSOCIATIONS OF THE SUBJECTS OF THE VOLGA FEDERAL DISTRICT OF THE RUSSIAN FEDERATION (FEBRUARY 1, 2018)

\begin{tabular}{|l|l|l|}
\hline \multicolumn{1}{|c|}{$\begin{array}{c}\text { The subject of the Russian } \\
\text { Federation }\end{array}$} & \multicolumn{1}{|c|}{$\begin{array}{c}\text { Association of } \\
\text { property } \\
\text { owners }\end{array}$} \\
\hline Kirov Region & 854 & 153 \\
\hline Nizhny Novgorod Region & 1603 & 397 \\
\hline Orenburg Region & 342 & 178 \\
\hline Penza Region & 600 & 25 \\
\hline Perm Krai & 1819 & 273 \\
\hline Republic of Bashkortostan & 1046 & 124 \\
\hline Mari El Republic & 461 & 28 \\
\hline The Republic of Mordovia & 959 & 16 \\
\hline Republic of Tatarstan & 1192 & 167 \\
\hline Samara Region & 1384 & 251 \\
\hline Saratov Region & 842 & 429 \\
\hline Udmurt Republic & 592 & 119 \\
\hline Ulyanovsk Region & 356 & 77 \\
\hline Chuvash Republic & 502 & 36 \\
\hline & &
\end{tabular}

According to the Federal Tax Service of the Russian Federation in the Volga federal district, 12,552 homeowners 
were registered. Their distribution by region is shown in Figure 2.

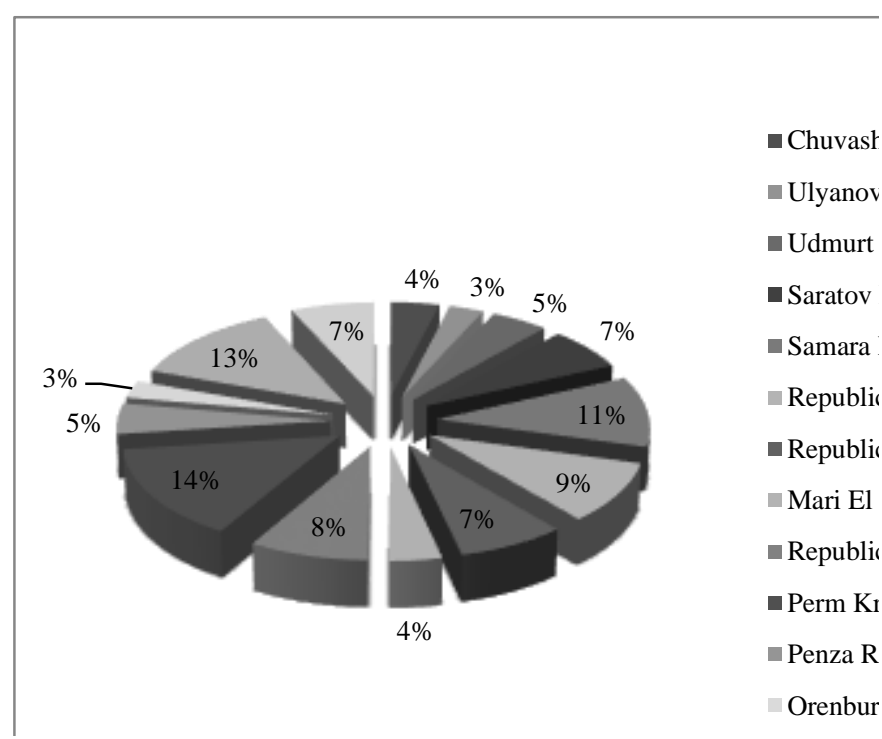

Fig. 2. Distribution of homeowners' associations in the subjects of the Volga Federal District (1 January 2018).

Article 53 of the Civil Code defines the legal entity. The legal entity shall acquire civil rights and assume civil obligations through its bodies.

Homeowners recognize the supreme governing body of a general meeting of members of the partnership.

\section{THEORY}

Let us draw ordering by analogy with the general meeting of proprietors and general meeting of shareholders [4, 5].

So, there is periodicity of differentiating annual and extraordinary general meetings of copartners.

The annual general meeting is conducted once a year in terms and is in order that partnerships established by the charter. With a view of unification of positions of charters acting in territory of the Russian Federation of partnerships of a part of 1 clause 145 of the Housing Code of the Russian Federation [6] to add with imperative position: «Annual general meeting of copartners of proprietors of habitation is assembled at the initiative of board of partnership not later than 60 (sixty) days after the termination of fiscal year»». Besides it is legislative to specify a circle of questions which should be without fail included in the agenda and are considered at the annual general meeting of copartners.

Besides annual general meeting in the partnership of proprietors of habitation so-called extraordinary meetings can be held. By analogy with the rate of clause 45 of the Housing Code of Russia, it is possible to tell that the convocation feature of the extraordinary meeting of copartners of habitation proprietors is that it can be assembled by any person who is the copartner of proprietors of habitation. Preparation of conducting the general meeting of copartners is performed by the person who is the initiator of its carrying out [7].

Carrying out general meetings of copartners is conducted as internal voting, correspondence voting, and also internallycorrespondence voting.

So, the general meeting which is conducted in the form of internal voting of copartners is a meeting when decisions concerning the agenda should be accepted during direct (direct) participation of copartners in the discussion of questions of the agenda and decision-making on the questions put on voting. At the general meetings which are conducted in the form of internal voting, participants of the meeting (copartners of proprietors of habitation) have the right to make decisions on any question of the agenda brought to the exclusive competence of a general meeting. It is necessary to consider that in the form of internal voting one can conduct both annual and extraordinary general meetings of copartners of proprietors of habitation.

In case of absence of the quorum necessary and sufficient for decision-making on acknowledgement of general meeting taken place when carrying out a general meeting of copartners in the form of internal voting, further decision of general meeting of copartners concerning the same questions of the agenda can be accepted, which has been conducted by correspondence voting.

So, the general meeting of copartners which is conducted in the form of correspondence voting, is a general meeting on which decisions concerning the agenda, put on voting, should be arranged in writing and transferred in a place or to the address which are specified in the message of carrying out of the specified general meeting or voting is performed with system use. That is the general meeting of copartners of proprietors of the habitation, conducted in the form of correspondence voting, can make decisions without a direct joint presence of members for discussion of questions of the agenda and decision-making concerning the agenda.

Taking part in the general meeting, which is conducted in the form of correspondence voting, the copartners which decisions are received to an expiry date of their acceptance are considered.

The new form of carrying out general meeting of copartners of proprietors of habitation - internallycorrespondence - represents symbiosis of before existing forms of its carrying out and provides possibility of internal discussion of questions of the agenda of the copartners who were present at the meeting, and made relevant decisions concerning the summons, taken out on voting. And there is also possibility to transfer agreed conclusions concerning the address specified in the notification of carrying out the general meeting of copartners.

\section{FINDINGS AND DISCUSSION}

From the Housing code of Russia, the list of the questions is brought in the exclusive competence of general meeting of copartners. They offered 2 clauses 145, obligatory inclusion in 
the agenda and consideration at the annual general meeting of copartners of the following questions:

1) Establishment of the size of obligatory payments and installments of copartners.

2) Statement of an order of formation of the fund on carrying out of major repairs of common property in an apartment house and its uses, and also the statement of reports on the use of such funds.

3) Determination of directions of use of the income of partnership economic activities.

4) The statement of the annual plan of the maintenance and common property repair in an apartment house, the report on the accomplishment of such plan.

5) The statement of estimates of incomes and expenses of partnership of the year, reports on the execution of such estimates, audit reports (in case of carrying out auditor checks).

6) The annual statement about the activity of board of partnership.

7) The statement of the conclusion of a revision committee (auditor) of partnership based on the results of testing the annual accounting (financial) reporting of the partnership.

8) Consideration of complaints to actions of the board of partnership, the chairman of the board of partnership and a revision committee (auditor) of the partnership.

9) Accepting and change on representation of the chairman of the board of partnership of regulations of partnership concerning workers which obligations include the maintenance and common property repair in an apartment house, positions about payment of their work, the statement of other internal documents of the partnership provided by acting Housing code, the charter of partnership and decisions of general meeting of copartners.

10) Determination of rate of commission of trustees of partnership, including the chairman of the board of partnership.

11) Other questions provided by the charter of partnership.

It is admissible that the questions, contained in the list specified above, can be considered at extraordinary meetings, however, their consideration at the annual general meeting should be obligatory.

As it has been told above, it is offered to make obligations of board initiation of carrying out annual general meeting, as the initiation of carrying out extraordinary general meetings of copartners habitation; this question should be settled by the charter of the corresponding meeting: possibility of initiation of carrying out extraordinary general meetings can belong to both the board and the chairman of the board individually, both to members and to a revision committee (auditor), and the copartner of habitation proprietors.

By analogy to the rules applied to the activity of joint stock companies, in the Housing code of Russia, in our opinion, it is reasonable to specify the number of cases when the partnership board is obliged to make the decision on convocation of the extraordinary general meeting, such as:

1) Reduction of a quantitative railroad train of the board to such limit when there is no quorum provided by the law.

2) The preschedule termination of powers of the chairman of the board if the election of the chairman of the board as the charter is carried to the competence of general meeting of copartners.

In the specified cases, extraordinary general meeting should be conducted not later than 30 days from the date of the approach of the circumstances underlying appointment of the extraordinary general meeting of copartners if other (smaller) term is not provided by the partnership charter.

Also it is necessary to fix legislatively a rule, according to which in case during established by board, it is not accepted the law or the charter of partnership of term the decision on convocation of annual or extraordinary general meeting of copartners, any copartner of proprietors of habitation has the right to address in court with the requirement about compulsion to conduct corresponding general meeting, and also to provide managerial responsibility concerning persons to whom the obligation of convocation of meeting and which have ignored the given obligation is assigned.

Thus in a judgment about the compulsion to conduct annual or extraordinary general meetings of copartners of proprietors of habitation terms and an order of its carrying out should be specified. Judgment execution can be assigned to the person who has addressed in court the corresponding statement (claimant), or partnership controls (the chairman of the board or board). In case of carrying out the general meeting of copartners to execute a judgment, the claimant of all expenses is connected with the preparation and carrying out of the meeting, should be compensated at the expense of partnership means.

In our opinion, entering of the specified positions will allow us to speak about additional guarantees to copartners not only in questions of carrying out extraordinary but also annual general meetings. As in practice there are cases when by the various reasons, throughout the long period of time, neither annual nor extraordinary general meetings simply are not conducted.

In the decision of the copartner of proprietors of habitation on the questions put on voting, the following should be specified:

1) Data on the person participating in voting.

2) Data on the document confirming an ownership right of the person, participating in voting, on premises in a corresponding apartment house.

3) Decisions on each question the agendas expressed by formulations pro, contra or "has refrained".

Legislatively the order of a direction (delivery) of bulletins is not fixed. The decision of this question, apparently, it is assigned to partnerships of proprietors of habitation: in the 
charter, the method an order of a direction (delivery) of bulletins can be provided: the voting slip can be or is handed over under a list to each copartner personally, or directed by them usng the letter of special delivery with the notification, or handed over as dispatched) by different ways provided there is the charter of partnership.

There is a question: what negative consequences can come out because of non-observance of the given procedure? It is necessary to name the most widespread consequence of infringement of the specified rule risk of circulation of the copartner of proprietors of habitation in the court with the aim of declaration of a contest of decisions of the conducted general meeting, and the report of the meeting constitutes the results of its carrying out. The developed court practice testifies that the decision, accepted by the general meeting, can be appealed in the court again in the event that the copartner of proprietors of habitation does not take part in this meeting and if such decision breaks one's rights and/or legitimate interests [8].

\section{CONCLUSION}

As the results of the conducted research of general meeting of copartners of habitation proprietors, it is reasonable to generalize some features of the supreme body of management of partnership of habitation proprietors - a general meeting of copartners.

First, participating in the general meeting and making decisions concerning the agenda, taken out for the voting, each member of a civil-law community (a partnership of proprietors of habitation) thereby implements the participation right in the management of partnership.

Second, the general meeting of copartners is allocated by the exclusive competence to determine the system of controls of the partnership.

Third, a general meeting of copartners is the controls allocated with the right to accept local normative acts, providing normal functioning of activity of not only partnership of habitation proprietors as a whole, but also its controls in particular: the general meeting of copartners, the board, the chairman of the board, a revision committee, etc.

Fourth, the will is generated by copartners of proprietors of habitation, and the actions made by them are considered as will and actions of the legal entity by means of special legal technics.

Fifth, the general meeting of members is a unique body of the partnership of proprietors of habitation, in which relation a special procedure of its formation as the status of the body of the general meeting of copartners of habitation proprietors is acquired from the moment the state registration of partnership of habitation proprietors is not provided.

\section{References}

[1] Civil code of the Russian Federation (part the first) 30/11/1994 №51, Legislation meeting, 12/5/1994, №32, Item 3301.

[2] The concept of development of the civil legislation of the Russian Federation (it is approved by the Council decision at the President of the Russian Federation on codification and enhancement of the civil legislation from 07.10.2009), Bulletin of the Supreme Arbitration Court of the Russian Federation, №11, November, 2009.

[3] L.Z. Gazizullina, The competence of general meeting of copartners of proprietors of habitation, International Business Management, 2015, №9, pp. 753-755.

[4] E.M. Hegaj, Legal status of general meeting of shareholders under the Russian legislation: an order of the organisation of work, accepting and the appeal of decisions: Dissertation on competition of a scientific degree of the candidate of jurisprudence, Moscow, 2009.

[5] S.D. Mogilevsky, Control economic societies: legal aspect, Moscow, 2001, pp. 122-123.

[6] Housing code of the Russian Federation 29/12/2004 №188, Legislation Meeting, 1/3/2005, №1.

[7] E.A. Sukhanov, Juridical persons as participants of civil legal relationship, pp. 240-242.

[8] T.I. Abdreev, A.M. Tufetulov, Legal status of an appraiser in the Russian Federation under globalisation, Mediterranean Journal of Social Sciences, Vol. 5, №24, November 2014, pp. 188-192 